\title{
Mughal Forts in Delta: An Essay on Fort Planning on the Rivers of Bengal
}

\author{
Sajid-Bin-DOZA \\ University of EVORA, Evora, Portugal
}

\begin{abstract}
“Huge intelligent structure” was built by the Mughal Heroes in this Subcontinent. ${ }^{1}$ It was the process to prevent and to secure a city as well as the territory from any kind of disruption and disintegration through the fortified walled profile. The strategies, approach, and positioning of those forts were governed by the contextual specification. All different forts of Mughals Empire had unusual notion of accomplishment. Fort architecture in the subcontinent was initially developed by the Mughals to protect the territory from the enemy. Later, those forts became huge and complex. The planning approach and the morphology of the fort architecture were justified according to the relative factor. The Mughal Fort is a Medieval-era building. The Mughal Fort improves the city's defensive strength and provides some culture at every turn. Building Walls is a prerequisite to settle the Mughal Fort. The Mughals were concern about environment. Mughals ruled most of the subcontinent until the mid-19th. During their rule they constructed elaborate forts across the countryside which served as administrative centers and living quarters for the occupiers. Bengal became a province of the Mughal Empire and was ruled from Delhi by the governors of Bengal (1576). ${ }^{2}$ Bengali river fort experienced lots of local and traditional influences only for being the river fort, stating from the component, elements of forts, and formal profile as well. Undoubtedly, Bengal conceived a different kind of river oriented fort, which has distinct characters. Even in the case of this fort formation, the Mughal had some strategic planning and morphology for spread city beyond the fort wall. The objective of the research is solely to identify distinguished characteristics and context specification and to analyze the morphology of the four-river fort architecture of East Bengal (Bangladesh).
\end{abstract}

Keywords: river fort architecture, huge intelligent structure, defence, fortification, physiognomy, cultural heritage

\section{Introduction}

In the political area, Bengal had experienced ruling since the Buddhist, Hindu, Sultanate, Mughal, and lastly the Colonial monarch. Moreover, this region was also the precious hub of cultural congregation. Therefore, the monarchy of the Bengal in different times embedded with mixture of ritual and cultural diversities. In the beginning, human being always seeks for the protection and safe accompany. It is so indigenous for the human settlement and then it became as the part of the household and onwards the fortification for the city. The huge

Sajid-Bin-DOZA, Architect and Doctoral Student of History f Arts, Erasmus Mundus Student, University of EVORA.

\footnotetext{
${ }^{1}$ A large distinguishable part of a continent, such as North America or the part of Asia containing India, Pakistan, and Bangladesh.

${ }^{2}$ During the reign of Akbar the Great.
} 
gigantic infrastructure turned into the fort and fortress of the city. In Bengal, the situation was unique. To prevent enemy attack, various mud fort was built during the Sultanate period (1298-1559). Fort is a structure used for the purpose of defence against attacks and usually having troops stationed. Generally, there are two types of fortifications: permanent and field one. The former is usually of great strength, erected in times of peace as a defence against attacks. It is meant to defend cities, border outposts, sea or river coasts, and trading centers. Permanent fortifications include walls, castles, forts, and fortresses. Field fortifications are constructed hastily in time of wars. They include trenches, foxholes, weapon emplacements, minefields, breastwork made of logs, mud walls, and obstacles such as barbed wire (Begum, 2004).

It was told before that Bengal was consisted of mud forts and those forts were generally called Durgo. ${ }^{3}$ This term popularly applied to all kinds of fortification. This term "fort" can be synonymous, such as duar, kot, burj, khitta, damdama, and chauki etc.. ${ }^{4}$ The topographical specialty of the terrain of Bengal turned into the unique morphology for the case of river forts. In the riverine Bengal, the fortification was established at the junction and mouth of the rivers. Defence system has molded in another Dimension for this region, having been in this climatic situation the river fort of Bengal evolved with innovative ideas and approach, at the same time flooding and monsoon time made the defence system impregnable. River of Bengal acted as the arteries, greatly responsible for shaping up the Bengal's river forts. Some records refer to have the existence of numerous mud forts from north to the south in Bengal (Banglapedia, 2006). The climate, geography, and the material perused to emerge the strength of Bengal's forts dependences predominantly on the natural mechanism defences and not only on their fortified walls. The earliest fort of Bengal, the Pundrabardhan ${ }^{5}$ city was fortified. The city was facilitated of having the Karaotoya River as well as fortification. The partial rectangular shape fortified walls was massive thick and the bastions are still evident showing their sense of fortification. However, the entire fortified city was dug-up with trance/moat to prevent enemy's attack.

In Bengal, the Hidu kings and Muslim immensely influenced fort and fortification. The fort and fortification of Mediaeval Bengal was seen as exemplary and many later forts have grown out of the synthesis of the two main sources: the pre-Muslim tradition of the land and the art of the building forts brought by the Muslims. The fort architecture was developed and elaborated in the two distinct phases: the Sultanate and the Mughal ones. It lingered 500 years long.

\section{Purpose of the Research}

Find the reason or any philosophical concept behind making this "huge intelligent structures".

Identify the formal expression and setting of the context through the pictographic and technical documentation.

\footnotetext{
${ }^{3}$ Durgo: The fortified premises surrounded by battlements and thick high wall for the resistance, and moat or trench was offset surrounds.

${ }^{4}$ Fort, Banglapedia, 2006, www.banglapedia.org/HT/F_0168.HTM.

5 The word "Pundra" owes its origin to a disease called "Pandu". The land where most of the people were suffering from that disease was called Pundrakshetra (land of Pundra). Punda is a species of sugarcane. The land where that species of sugarcane was extensively cultivated was called Pundadesa (land of Punda). According to later Vedic texts like Aitereya Aryanaka of 8th-7th century BC, the Pundra was a group of non-Aryan people who lived east of the river Sadanira. The Mahabharata also made a similar reference. In the 1st century AD, the land was mentioned as Pundravardhana for the first time in Asokadana.
} 


\section{Scope of Research}

The research will try to come up with the development dynamics and suggestion of guidelines for conservation. Critical illustrations will be worked out to analyse the stylistic aspects, formal understanding, spatial pattern, the traditional forces, and above all the formal relationship between and within the structures; their spatial sequences, functional clarity, and philosophy of making the typical complex fort. A literary strong documentation and architectural sketches will reinforce the research.

\section{Research Methodology}

A detailed literature survey would be done to set a framework for the identification and analysis of development. Literature survey and related book reviewing are the parts of the methodology.

Analysis and identification may be done in three stages.

\section{Huge Intelligent Structures}

Intelligent structure could be termed as the means which is with proficient structural advancement, the structure which has the diversified functional curriculum, structure that grew with "purposeful" technique, and having purposeful building this kind of configuration which is associated with supportive and special tasking. Such situation was observed during the medieval period. It was comprehensive to build structure in such manners. Setting, availability of building materials, traditional craftsmanship, the nature of the course of waterway, and lastly the strategy of positioning the placement for the river fort were the identical key elements to settle the mega fort structure.

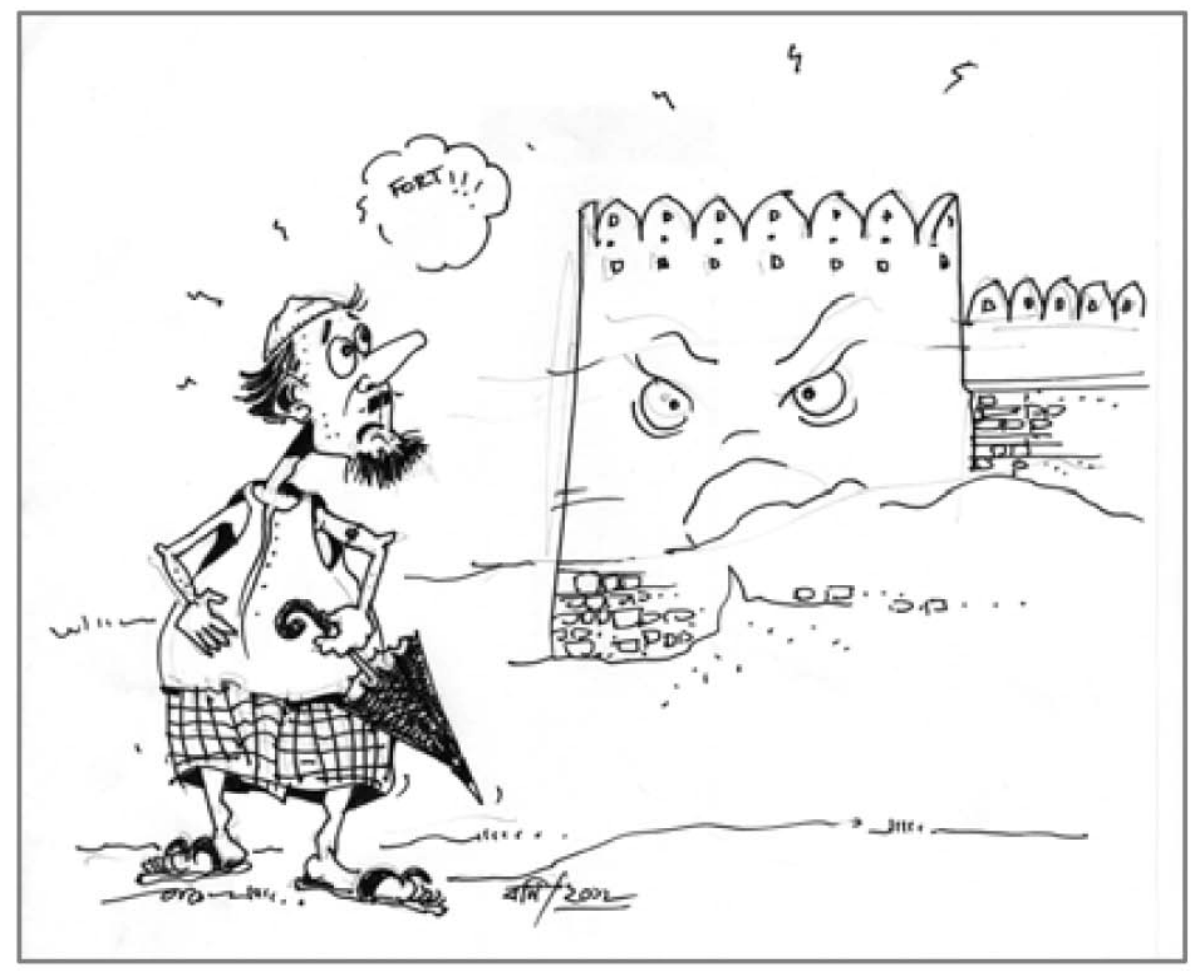

Figure 1. A cartoon drawn by the auther showing the curicity of a common people adout the huge fort structure. 


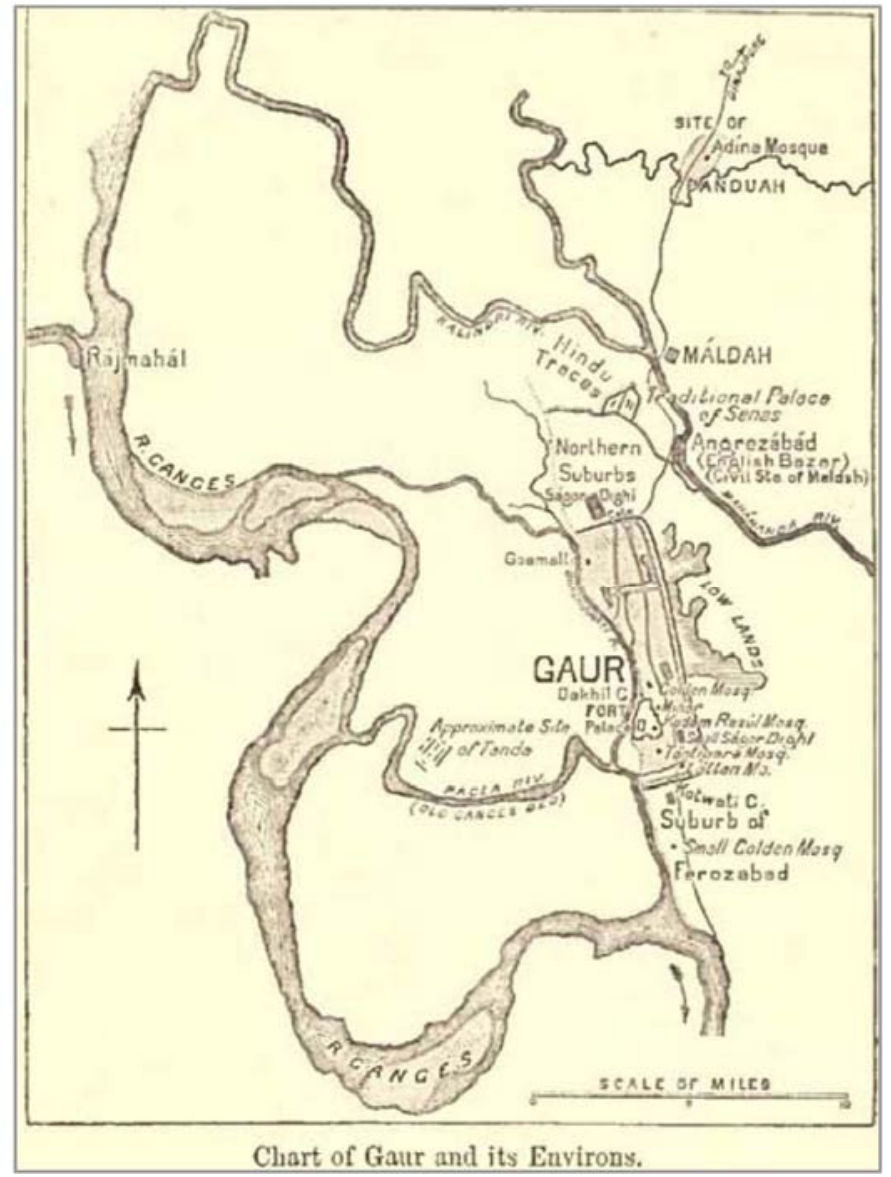

Figure 2. Chat of GAUR and the environs.

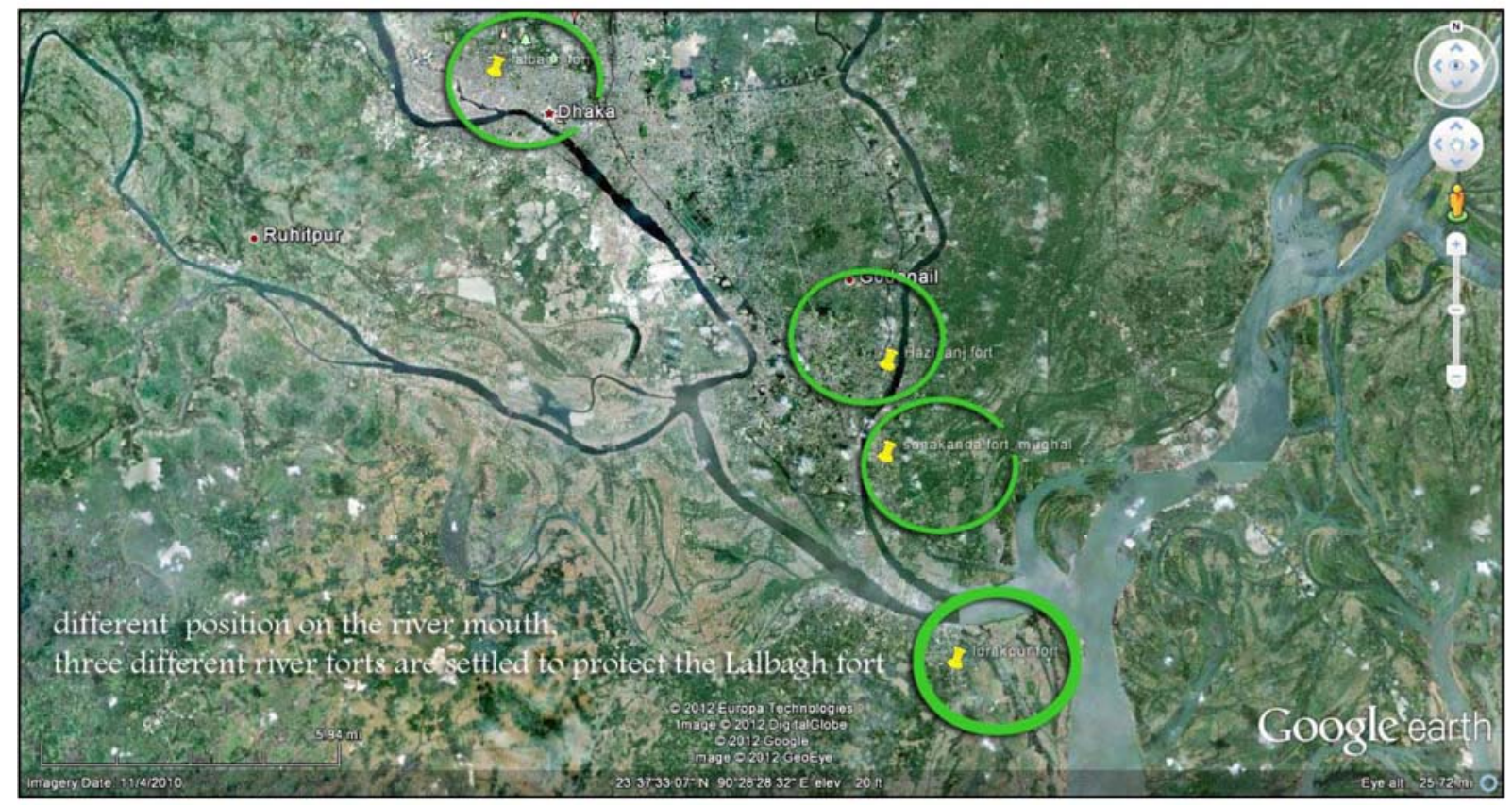

Figure 3. Different position of the river mouth, three different river forts are srttled to protect the Lalbagh fort. Source: Goodle earth 2012. 

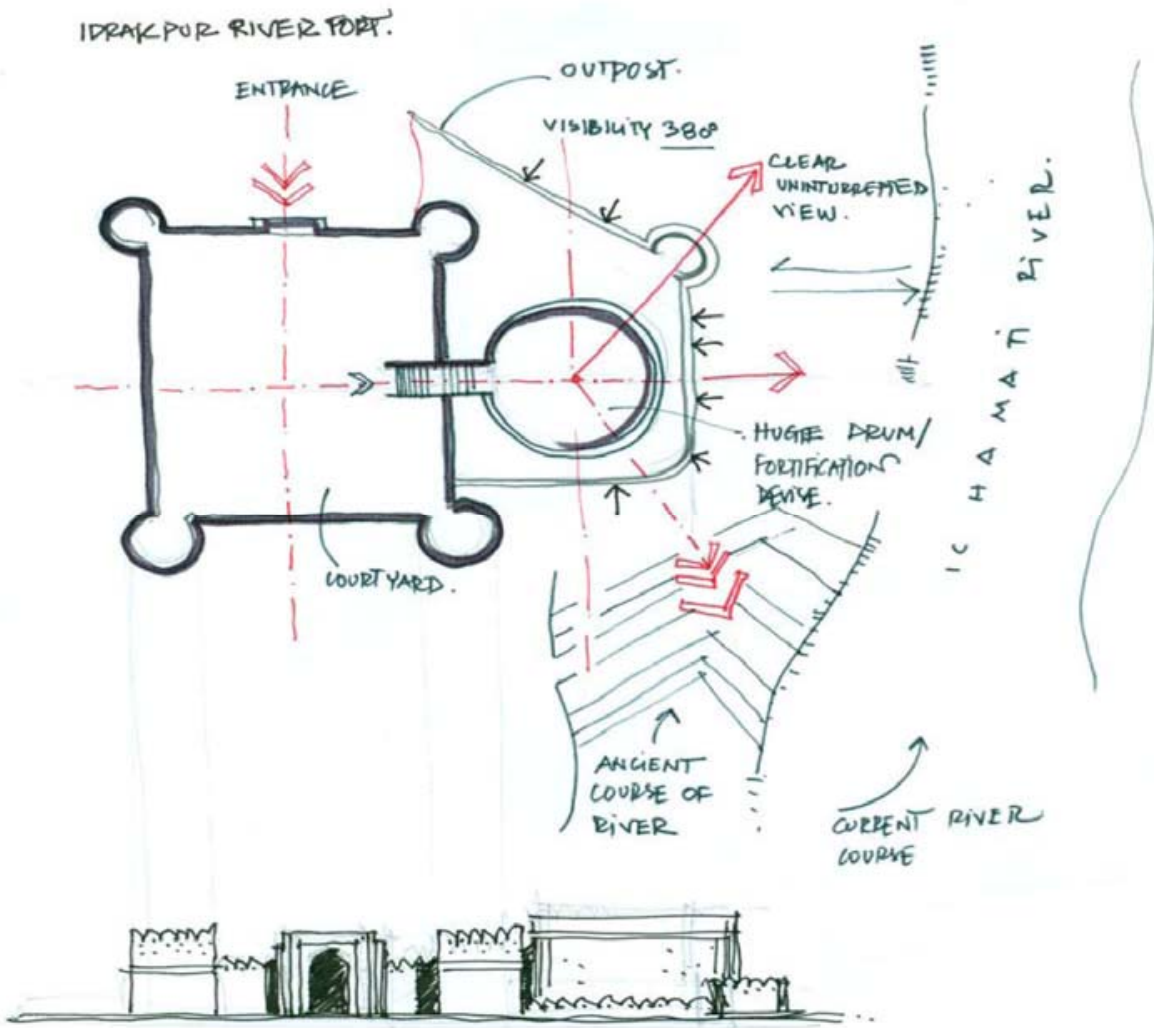

Figure 4. The diagram shows the Idrakpur river fort situation with the river embankment.

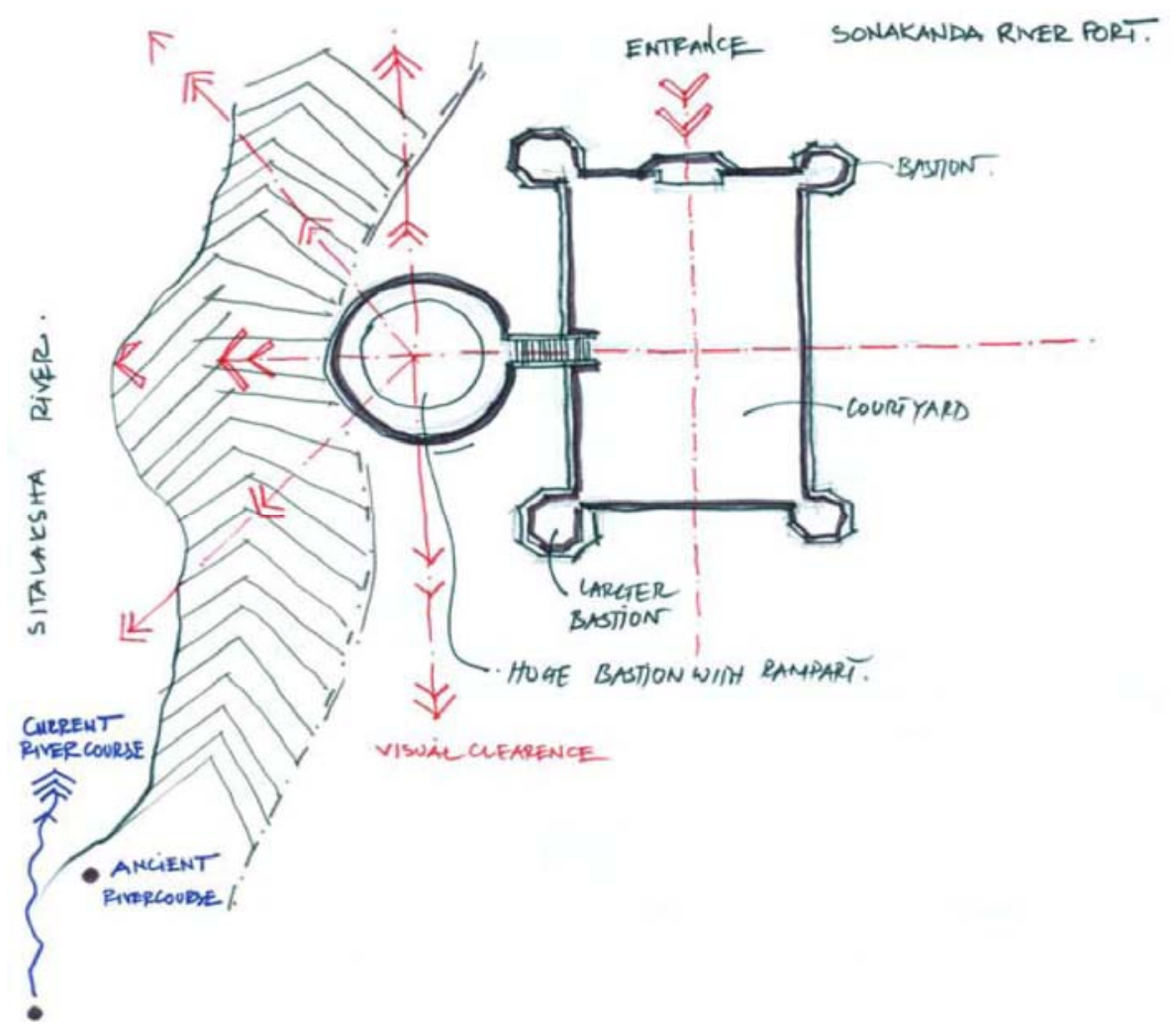

Figure 5. The diagram shows the Sonakanda river fort situation with the river. 


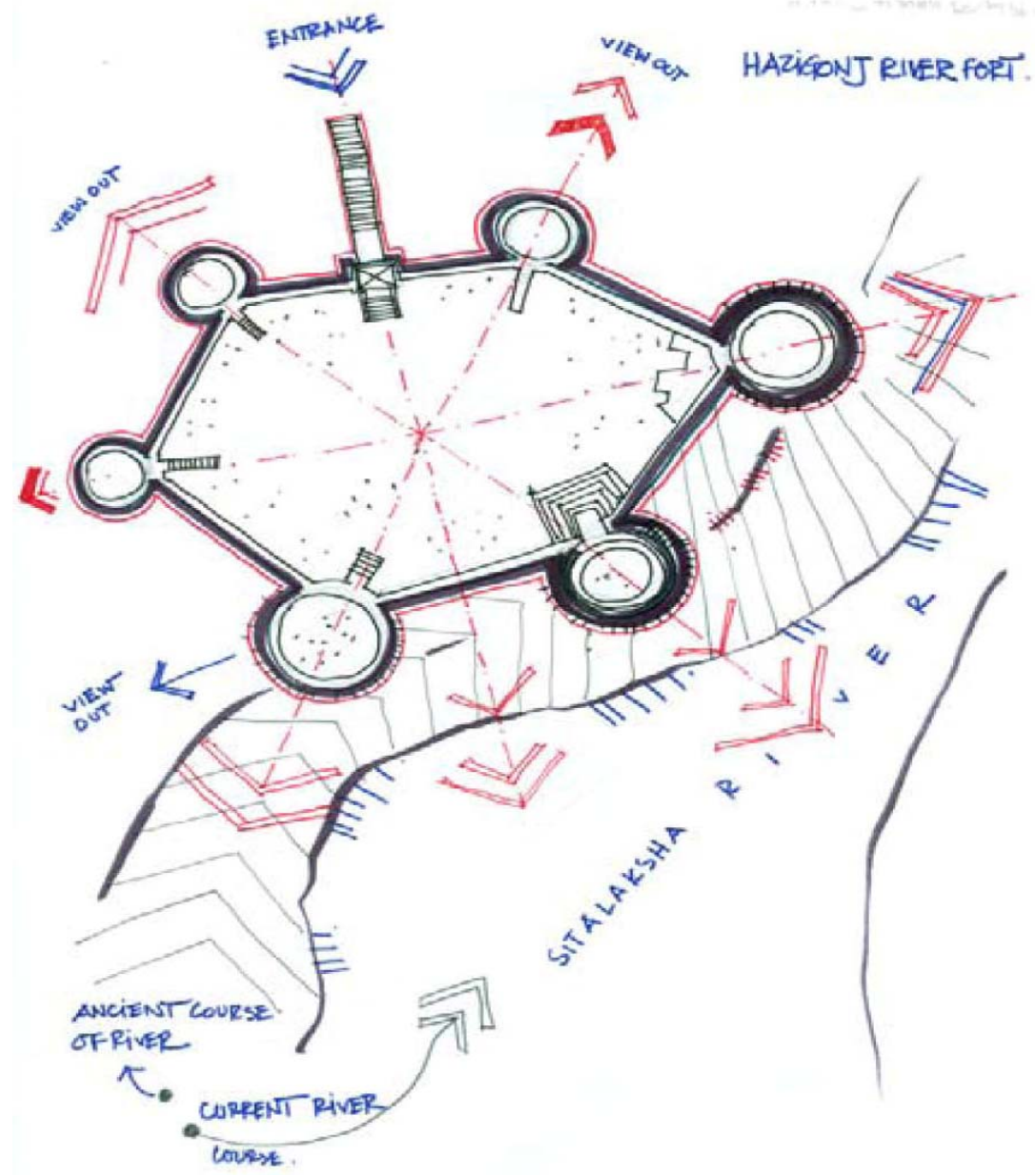

Figure 6. The diagram shows the Hazigonj river fort situation with the river embankment.

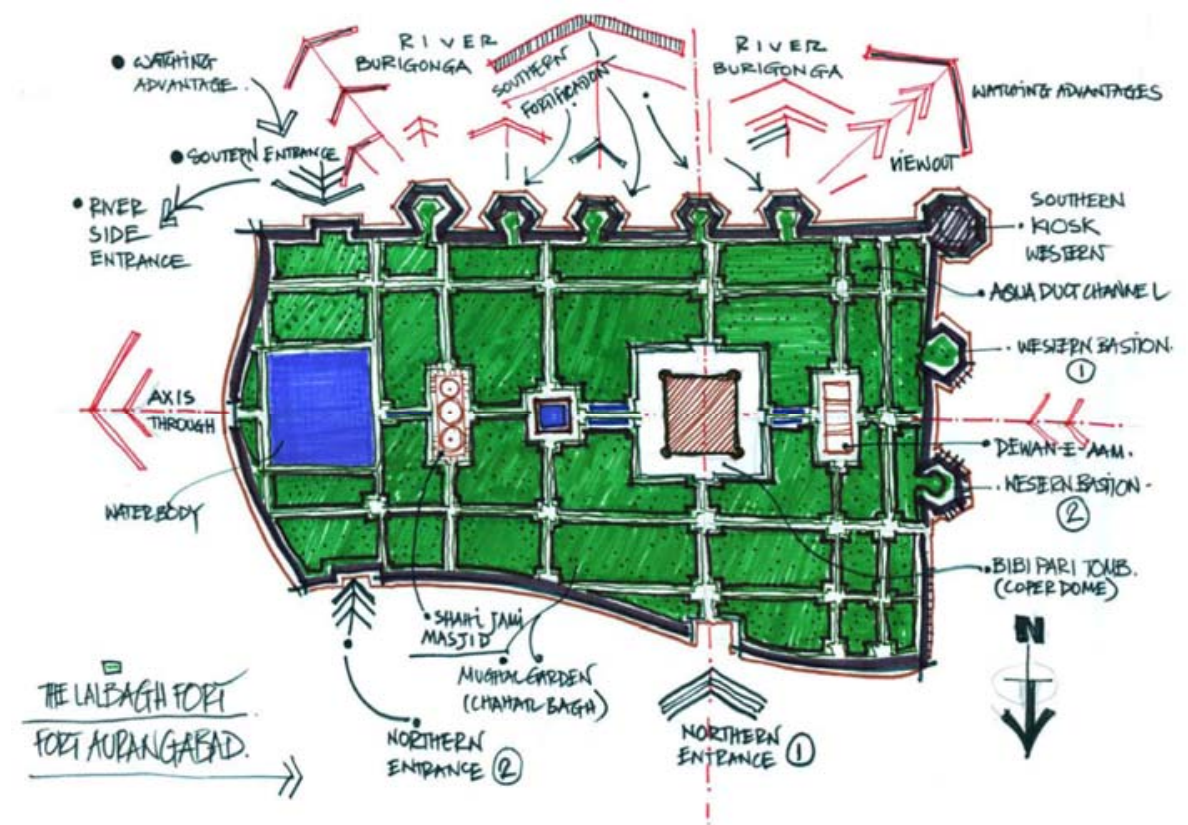

Figure 7. The diagram shows the Lalbagh river fort situation with the river embankment. 


\section{Strategy Behind Site Selection for the River-fort}

The Mughals built unique river fort in Bengal, Gaur ${ }^{6}$ is another best example among these (see Figure 2). Unfamiliar geo-physical environment shaped the river fort architecture of in an expressive silhouette; the flat land and the river with tidal force along with the critical setting the fort used to build up. On the northern region of Bengal, the defence system of the fort was allocated just on the mouth of the river so that the enemy could not get into the internal navigation channel. Once the outer navigation flow is blocked or protected, it was impossible to penetrate through the outer navigation network to the inner route. The sovereign chose major junctions of the river route. The connectivity, stimulation, course of action, and the settings of land are along with physiographic formation of the river and land were totally a synchronized phenomenon to house a river fort. Peculiarities in land formation evolved fort architecture of in forceful characteristics from the other forts of the sub-continent. Most of the mud fort used to build during the sultanate era and these forts used to choose the site on the comparative elevated land for the clear vision. Sometimes the elevated ground was developing by digging up the land with the proper fortification-planning moat designed. Sometimes the colonel chooses the natural rampart for fortification also.

Therefore, the strategy of choosing the site was mainly evolved with the location matter, basically on the deltaic edge or mouth (see Figure 3) the Pre-Mughal and the Mughal people established the mega structure like river fort. Advantage of waterways, ground-height, rampart, tidal force of river, and the slope of the embankment were the main involved components of establishing the river fort of Bengal. The sultans took necessary defensive measures and evolved river forts in the delta. The river forts mark a blending of the defensive requirements of the sultans and the physiographic peculiarities of Bengal (Begum, 1996).

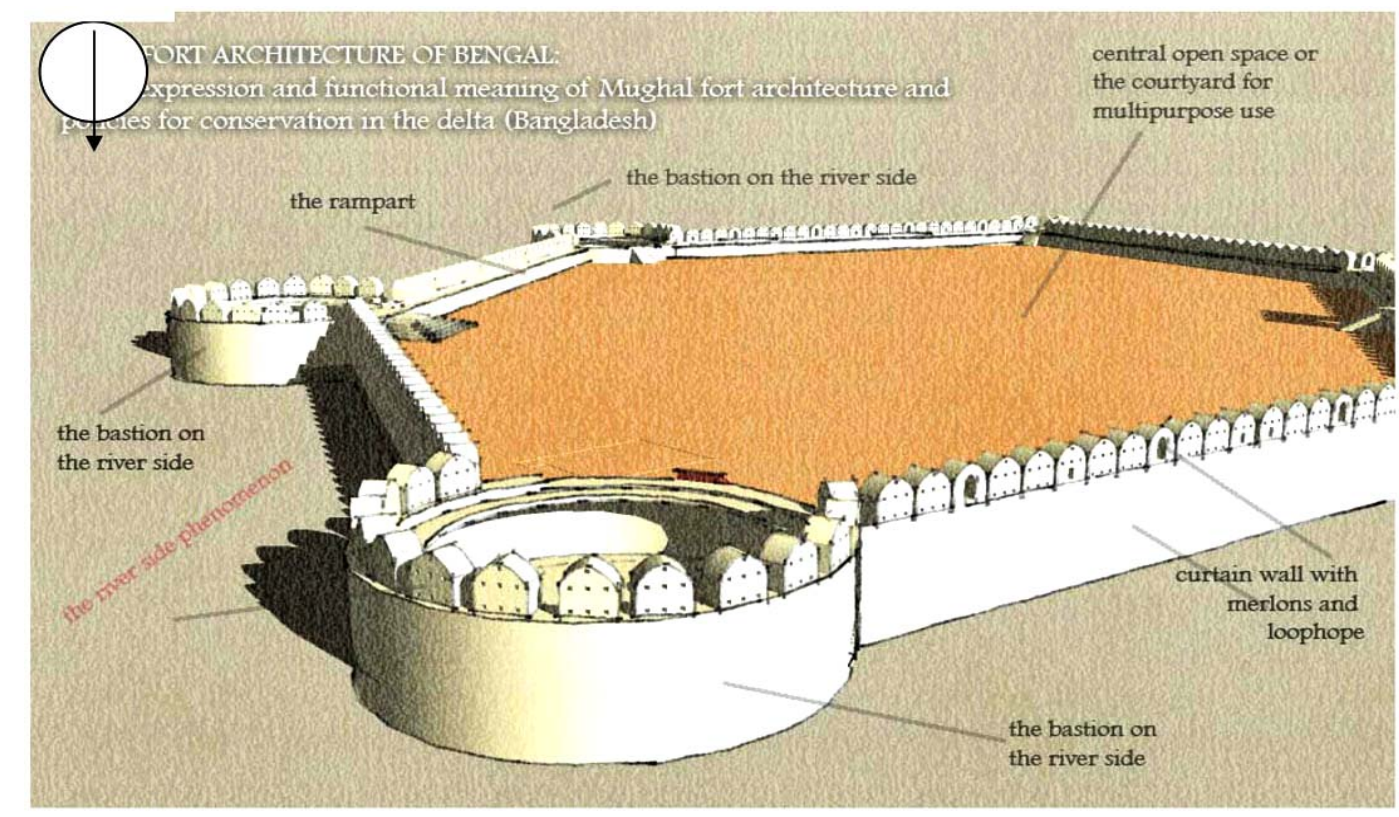

Figure 8. The bastion of the Hazigonj river fort, is placing towards the river side to catch all sights.

\footnotetext{
${ }^{6}$ Gour, or Gaur (Bengali: গఢ·̦), as it is spelt mostly in modern times, or Lakhnauti is a ruined city, in the Maldah district of West Bengal, India, on the west bank of the Ganges river, 40 kilometers downstream from Rajmahal. Gaur became the glorious capital of Sultanate Bengal.
} 


\section{Summary and Basic Characteristics of Mughal River Fort}

(1) The Mughul river fort is only with the thick and bastion fortified walls the Mughals used to follow the strategy of making fort on the water.

(2) The river mouth, the elevated land, junction of two or three secondary rivers, inner navigation route were the popular sites for choosing the river fort of Bengal.

(3) The river fort of Mughal is consists of a single entrance with Mughal "entrance-emblem".

(4) The marlons of the thick walls have identical value to express the "Mughlai-façade".

(5) Most of the river forts consist of one or several important bastions and the artillery elevated drum (see Figure 8). These elements were engaged in plan to provide clear vision.

(6) Some river fort is leveled with rampart surrounded like the Hazigonj river fort is one of them (see Figure 6). The rampart or the elevated terrace was used to help the proper fortification system for the Mughal soldiers.

(7) Sometime tower was used in the river side façade to have the clear look toward the flatland of delta.

(8) The bastion of the river fort has varieties. Some of them are circular and some of them are polygonal. Idrakpur fort and Hazigonj fort, all these are having the cylindrical bastion. Both the Lalbagh (see Figure 7) and the Sinakanda forts (see Figure 5) consist of polygonal bastion.

(9) All the forts of Mughal Bengal are conscious about the orientation. All the forts grew up addressing the river course foe example, giant bastions are comparatively bigger in form and the bastion at the land side is bit smaller.

\section{Conclusion}

Indeed the river fort architecture of Bengal is resourceful and could be termed as the powerful massive "deltaic solution”. The fertile and flat land moulds the defensive architecture in to a native form. However, very few river forts have survived the ravages of time. Nevertheless, an interesting group of fortress was built in the 17th century by the Mughal, which guarded the water routes towards Dhaka against the recurrent plundering raids of the Arakanese and Mugh pirates. The paper tried to identify and to analyze the fort characteristics, their strategically location for setting, the technique of safeguard from the pirates and lastly the context specificity of making this kind of river fort with some unique morphology. It is evident in the research that the technique and the process to house a river fort were pre-learning from the Hindu Kings of North-Eastern part of Bengal. By the course of time the Mughals adopted to build the river fortress in this plain land, it became comprehensive for them to find the opportunities of establishing mud river fort in this region. From the history, it is clear that in centuries, due to the changing fortunes of these highly vital frontier outpost, several types of both temporary and permanent structures were built within the fort and river-forts area. The Mughals had the notion of introducing the high test or the environment with the architecture as well as the structure. Although they were new in Bengal but well off kingdom in Delhi Sultanate, the Mughal experiencing the other river fort was built by the sultans and the Hindu Kings. Perhaps, Mughal learnt lot of tips of fortification in this tropical region from the former kingship. Therefore, the existing three-river fort including the lalbagh fort, Mughal showed the act of the war in an art form. In addition, this act of war is entitled in the form of architecture as fortification. Bengal was never deprived by the Mughal, particularly for the fort architecture. They examine, analyzed, tested, implemented, and lastly approached locale, for establishing such huge intillegent architecture. The result came out so strong, so 
bold, so specific, and soulful. In the arena of the architectural world, Bengal's river-fort style achieved the global platform. It is also noticeable for builders like Mughal to handle the structural articulation in the deltaic situation. Subsequently, the river networking and the marshland management were complicated issues to build a fort on it. Bricks were used fully for the construction of such bigger structure in the unfavorable land. Here the paper tried to induce the happenings of the river-fort's different phenomena, its growth, and critical comparison among them.

\section{References}

Ahmed, A. S. M. (2006). Mosque architecture in Bangladesh (pp. 40-41). Dhaka: UNESCO.

Ahmed, N. (1980). Islamic heritage of Bangladesh (p. 46). Dacca: Padma Printers.

Ahmed, N. (1984). Discover the monuments of Bangladesh (p. 149). Dhaka: University Press Limited.

Asher, C. B. (1984). Inventory of key monuments. Art and archaeology research papers: The islamic heritage of Bengal (p. 71). Paris: UNESCO.

Banglapedia. (2006). Fort. Retrieved from http://www.banglapedia.org/HT/F_0168.HTM

Begum, A. (1993). Lalbagh: The Mughal Fort. Journal of the Bangladesh National Museum, 2(1).

Begum, A. (1996). The Hajiganj fort and its architectural remains. Dhaka: National Academy of Fine \& Performing Arts.

Begum, A. (2002). Mughal fort architecture in Bengal with an introduction to some important river forts. Journal of the Asiatic Society of Bangladesh, 47.

Begum, A. (2004a). Mughal forts in bangladesh: An architectural study. Proceedings from IAHA'04: The 17th Conference of International Association of Historians of Asia. Dhaka.

Begum, A. (2004b). Mughal forts in South Asia: An architectural study. Proceedings from IAHA'04: The 17th Conference of International Association of Historians of Asia. Dhaka.

Brown, P. (1942). Indian architecture (pp. 1-5). Bombay.

Dani, H. (1961). Muslim architecture in Bengal. Dhaka: The University press Ltd..

Doza, S. B. (2008). Analysis and identification of spatial pattern of Rajshahi old town. Dhaka: BUET.

Frishman, M., \& Khan, H. U. (2002). The Mosque. London: Thames and Hardson Ltd.

Grover, S. (2002). Islamic architecture in India, New Delhi: Galgotia Pub.

Hasan, P.(1989). Sultans and Mosques in The early Muslim architecture of Bangladesh. London, I. B. Tauris \&o Ltd Banglapedia. Dhaka.

Hasan, S. M. (1979). Mosque architecture in pre-mughal Bengal. Dhaka: UPL.

Husain, A. B. M. (1997). Site and surroundings. In Husain, A. B. M. (Ed.), Gawr-Lakhnawti (pp. 1-8). Dhaka: Asiatic Society of Bangladesh.

Mowla, Q. A. (2003). Towards a paradigm of Liveable City-The case of Dhaka. In The Jahangirnagar Review (pp. 15-25). Jahangirnagar University.

Stewart,C. (1958). The size and spacing of cities. Geographical Review, 48, 223-45.

Tadgell, C. (2002). The history of architecture in India. Singapore: Phaidon Press. 